\section{Philosophy of Science}

AT a meeting held at University College, London, on June 1, a Philosophy of Science Group was formally constituted and affiliated with the British Society for the History of Science. The Group adopted the following statement of aims: "The purpose of the Group is to study the logic and method of science as well as of the various special sciences, including the social sciences. The main emphasis is upon an approach through the various special sciences to the philosophy of science." The Group intends to hold meetings for the reading and discussion of papers and to publish an account of its activities in a supplement to the Bulletin of the British Society for the History of Science, which will be circulated to members. The Group has elected the following Committee : Prof. H. Dingle (chairman), Dr. K. R. Popper, Mr. F. I. G. Rawlins, Dr. G. J. Whitrow and Dr. A. C. Crombie (honorary secretary), Department of History and Philosophy of Science, University College, Gower Street, London, W.C.1. It is hoped to hold the first ordinary meeting in the autumn of this year.

\section{Conference on Noise and Sound Transmission}

THE Acoustics Group of the Physical Society, in association with the Royal Institute of British Architects, is holding a three-day International Conference on Noise and Sound Transmission during July 14-16. This is the first major international discussion of the subject for many years, and papers will be read by European and American investigators in addition to the contributions from Great Britain. Among those reading papers are L. L. Beranek (United States) ; T. Vogel, R. Lehmann, P. Chavasse, F. Canac (France); W. Fürrer (Switzerland); W. K. Westmijze, C. W. Kosten, J. van den Eijk (Holland); F. Ingerslev, V. L. Jordan, P. V. Bruel (Denmark); E. Meyer, A. Schoch, L. Cremer (Germany); N. Fleming, R. S. Dadson, H. L. Kirke, W. A. Allen and A. J. King (Great Britain). The papers will cover the subjects of sound insulation in buildings, aircraft and ships; impact sound; resilient suspension systems; proposals for standardization of measurement, and the measurement of noise. Those who desire to have copies of summaries of papers in advance of the meetings should send requests to the Joint Honorary Secretaries of the Acousties Group at 1 Lowther Gardens, Prince Consort Road, London, S.W.7.

\section{International Congress of Industrial Medicine}

THE ninth International Congress of Industrial Medicine will be held in London, at the Caxton Hall, during September 13-17. The last congress was held in Frankfurt in 1938. The congress will meet in six sections devoted respectively to social aspects, environment, nursing, clinical studies, practice and legal and miscellaneous topics. Among the subjects announced for discussion are incentives, work and skill, dust hazards, pneumokoniosis, physical, biological and psychological effects of environment, effects of working with the newer chemicals and metals, hazards of radiant energy, etc. Further particulars can be obtained from the secretary of the Congress, Room 501, Garden Court Wing, B.M.A. House, Tavistock Square, London, W.C.1.

\section{Congress on Biological Chemistry}

THe Société de Chimie Biologique will hold its eighth congress in Paris during October 6-8. This will be the first international congress on the subject in France for ten years, the previous meeting having been held at Liège in 1946. Subjects for special consideration at the Paris congress are: proteins and hormones (reports by Profs. Theorell and Fromageot) ; biological organic chemistry and plant biochemistry (reports by Profs. Stoll and Janot); vitamins and hormones (reports by Profs. E. C. Dodds and Horeau). Sessions will also be reserved for communications outside these subjects, and provision will be made for experimental demonstrations. Further particulars can be obtained from the secretary-general of the congress, $M$. Jean Courtois, 4 Avenue de l'Observatoire, Paris, VIe

\section{Science and Industrial Practice in the Iron and Steel Industry}

THE British Iron and Steel Research Association is arranging two conferences to be held next autumn at Ashorne Hill, nr. Leamington. The first, in which the Institute of Physics is also interested, will be held on September 8 and 9, and is to discuss nondestructive testing of castings. Three sessions will be arranged to discuss papers on $\mathrm{X}$ - and gamma-ray methods and on $\mathrm{X}$-ray equipment, radioactive materials and radiography abroad; magnetic and ultrasonic methods; recent work by the Non. Destructive Testing Sub-Committee of the Association on the comparison of X-ray, gamma-ray and ultrasonic methods, and a paper on acceptance standards. It is intended that the papers shall deal essentially with the practical aspects of the subject and be of interest to executives not conversant with the methods, but who might be considering their use. The second conference is planned for October 21 and 22 , and is to discuss foundry core bonding agents. The object is to bring to the notice of founders the wealth of information that has been obtained in recent years on the new materials that may be used for the bonding of foundry cores. The use of such materials, in many cases with an appreciable reduction in cost, would enable the linseed oil used hitherto to be diverted to alleviate the shortage of edible fats. There will again be three sessions: natural resources of the materials, recent work by the Association on the practical and fundamental aspects of bonding, and the properties of new materials such as plastics and petroleum products; experience of founders with such materials; and the impact of these materials on matters such as core-blowing, and dielectric and infra-red heating.

\section{International Scientific Film Congress}

THE second congress of the International Scientific Film Association will be held in London during October 4-11. It is being convened by the Scientific Film Association of Great Britain, with the help of the British Film Institute. Three days will be devoted to business meetings of the Association, and three days to a festival of scientific films, when it is hoped to show many contributions from all the participating countries to members of the general public. The congress will close with a general assembly of the delegates on October 11. The Association was constituted last year in Paris by delegates from twenty-two countries who had accepted the joint invitation to the inaugural congress from the Scientific Film Associations of Great Britain and France. The primary aim of the Association is: "To raise the standard and to promote the use of the scientific film and related material throughout the world in order to achieve the widest possible understanding 
and appreciation of scientific method and outlook, especially in relation to social progress". Further details may be obtained from the Scientific Film Association, 34 Soho Square, London, W.1.

\section{Annual Reviews of Psychology and of Physical Chemistry}

AN "Annual Review of Psychology" is to be published under the auspices of Annual Reviews, Inc., Stanford, California, the first volume to appear early in 1950. Prof. Calvin P. Stone and Donald W. Taylor, of Stanford University, will serve as editor and associate editor, respectively. The editorial committee will consist of the following: John E. Anderson, Institute of Child Welfare, University of Minnesota; John G. Darley, University of Minnesota; Clarence H. Graham, Columbia University ; Carl I. Hovland, Yale University; James G. Miller, University of Chicago. The subject-matter of each volume will consist of critical appraisals of research proceeding in the major divisions of the field. Subjects of greatest activity will be reviewed annually, while those of lesser activity, together with any topics which encompass small divisions of the field, will be reviewed biennially.

Organisation of an "Annual Review of Physical Chemistry" of a similar type, operating under the same editorial policies and characterized by a corresponding recurring list of topics, is also announced by Annual Reviews, Inc. This will be edited by Prof. G. K. Rollefson, of the University of California, Berkeley, and will be directed in the selection of topics and authors by an editorial committee consisting of Henry Eyring, University of Utah; George Glockler, State University of Iowa ; W. F. Libby, University of Chicago ; J. W. Williams, University of Wisconsin; and E. Bright Wilson, jun., Harvard University. The first volume will also appear in 1950. Annual Reviews, Inc., is a nonprofit corporation which was first constituted in 1932 to publish the "Annual Review of Biochemistry". Since then it has initiated the "Annual Review of Physiology" (jointly with the American Physiological Society) and the "Annual Review of Microbiology".

\section{Zoological Society of India}

THE following have been elected members of the Executive Council of the Zoological Society of India : President, Dr. S. L. Hora ; Vice-President, Prof. D. R. Bhattacharya; Secretary, Dr. M. L. Roonwal; Editor, Prof. K. N. Bahl; Treasurer, Dr. B. S. Chauhan; Members, Dr. K. Panikkar, Prof. M. A. Moghe, Dr. B. N. Chopra, Dr. Bhattacharya, Dr. G. D. Bhalerao, Dr. D. V. Bal, Dr. T. J. Job. It is intended to bring out the first volume of the Journal of the Zoological Society of India this year. Papers intended for publication, which should be original contributions or critical reviews of current researches not published elsewhere, should be sent either to the Editor (at the Zoology Department, Lucknow University, Lucknow) or to the Secretary (at the Zoological Survey of India, Banaras Cantt., U.P.).

\section{University of Glasgow}

The University Grants Committee is supporting the development of electrochemistry in the University of Glasgow; and Dr. J. C. James, at present at Battersea Polytechnic, London, has been appointed lecturer in chemistry under this project. Similar support is to be given to zoological taxonomy. Other recent appointments in the University of Glasgow are: Mrs. Rhoda M. Ainley, assistant in anatomy; J. Highet, lecturer in sociology; A. W. Sloan, lecturer in physiology; Bruno Toushek, a Nuffield fellow in physics; Mrs. Jean A. Wapshaw, part-time assistant in biochemistry; and A. Williams, lecturer in geology (with a year's leave of absence while holding a Commonwealth fellowship).

Work has been begun on the final portion of the new Chemistry Department at Glasgow, and on the building which is to house the $300-\mathrm{MeV}$. synchrotron. A $30-\mathrm{MeV}$. instrument is already in operation in the Department of Natural Philosophy.

\section{Announcements}

Prof. T. DALLING, director of the Veterinary Laboratory of the Ministry of Agriculture and Fisheries at New Haw, Weybridge, has been appointed chief veterinary officer to the Ministry from August 21 on the retirement of Sir Daniel Cabot, who has reached the age of sixty. Sir Daniel Cabot's services will be retained part-time in a temporary capacity in connexion with certain international veterinary organisations.

Mr. Arfred Eastham, chief officer of the Official Seed Testing Station since 1923, retired on June 30 and the Council of the National Institute of Agricultural Botany has appointed Mr. C. C. Brett to this post. Mr. Brett has been senior assistant to the chief officer since 1922, and during the past eighteen months has been seconded as executive officer of the Seed Production Committee.

THE following have been appointed to readerships in the University of Edinburgh : Mr. E. G. Dymond (natural philosophy), Dr. W. L. Edge (mathematics), Dr. Alexander Nelson (botany) and Dr. E. G. V. Percival (chemistry).

THE autumn meeting of the Deutsche Physikalische Gesellschaft in der Britischen Zone will take place at Clausthal-Zellerfeld/Harz during September 9-12.

THE fourth Commonwealth Mycological Conference will be held at the Imperial College of Science and Technology, South Kensington, during July 19-24. Plant pathologists from all parts of the British Empire will be present, and the topics to be discussed include the control of virus diseases, with special reference to swollen shoot of cacao, measures to be taken to avoid the transmission of seed-borne parasites through the seed, the certification of healthy planting material of certain vegetatively produced crops, new developments in fungicides, including their application from the air, and forest pathology.

Ar the annual general meeting of the Institute of Welding on June 30 , the following were elected honorary officers for 1948-49: President, Dr. J. H. Paterson; Vice-President, O. V. S. Bulleid; Honor. ary Treasurer, W. E. Harriss.

THE Governing Body of the Imperial College of Science and Technology has decided that the schemes for the international exchange of students during summer vacations, initiated by its Vacation Work Committee in 1946, shall be broadened in 1949 to include university students from other colleges in Great Britain. The exchange is operated through the recently established International Association for the Exchange of Students for Technical Experience, which at present includes Belgium, Czechoslovakia, Denmark, Finland, France, Netherlands, Norway, Sweden and Switzerland. 